\title{
The Influence of Price, Brand Image, and Time Pressure against Purchase Decision and Customer Satisfaction (Case Study on Terminal 3 Departure's Passenger at Soekarno-Hatta International Airport)
}

\author{
Muhamad Septian Rangga Putra \\ Student of Magister Management, Mercu Buana University \\ Jakarta, Indonesia
}

\begin{abstract}
These research aims to discovered the influence from price, brand image, time pressure towards purchase decisions and its impact on customer satisfaction to passengers at Terminal 3 Departure Soekarno-Hatta International Airport . This research typed used explanative research which aims to analyze the relationships between one variable to another. The exogenous variables in this research were price, brand image, and time pressure, the endogenous variable as mediated in this research was purchase decision, while the endogenous variable was customer satisfaction. Research population were passengers who passed through terminal 3 departure at Soekarno-Hatta International Airport with sample size of 120 respondents. Data analysis technique in this research used Structural Equation Modeling (SEM) with assist from Linear Structural Relations (Lisrel) program version 9.2. The results had showed that 1) price had positive and significant impact towards purchase decisions, 2) Brand image had positive and significant influence on purchase decisions, 3) time pressure had positive and significant impact to purchase decisions, 4) purchase decisions had positive and significant affect to Customer Satisfaction.
\end{abstract}

Keywords:- Price, Brand Image, Time Pressure, Purchase Decision, Customer Satisfaction.

\section{INTRODUCTION}

The airport is a strategic location for business partners. It is great business opportunities because airports have an attractive market share from the number of service users or passengers. Based on Table 1, Soekarno-Hatta International Airport was ranked as the 17th busiest airport in the world, competed with airports in the top five airport, such as airports in the cities of Atlanta, Beijing, Dubai, Tokyo and Los Angeles. Therefore, with a very promising number of passenger statistics, Sokarno-Hatta Airport is a strategic location for business partners in Indonesia. The number of passengers at the airport could be used as a business partner when planning a business study.
Sri Hartono

Lecturer of Postgraduate, Mercu Buana University Jakarta, Indonesia

\begin{tabular}{cccc}
\hline $\begin{array}{c}\text { Airport } \\
\text { Location }\end{array}$ & Code & $\begin{array}{c}\text { Total } \\
\text { Passenger* }\end{array}$ & Rating \\
\hline Atlanta & ATL & 103.902 .992 & 1 \\
Beijing & PEK & 95.786 .442 & 2 \\
Dubai & DXB & 88.242 .099 & 3 \\
Tokyo & HND & 85.408 .975 & 4 \\
Los Angeles & LAX & 84.557 .968 & 5 \\
Jakarta & CGK & 63.015 .620 & 17 \\
\hline
\end{tabular}

Table 1:- List of Busiest Airports in the World 2017

Source: https://aci.aero/, Airport Council International (2018) (data processed)

The number of passengers arriving and departing via Soekarno-Hatta International Airport in Table 1 reaches $63,015,620$ passengers per year. This figure attracts business partners in opening a business at the airport. If we do simple calculation, when business partner estimates that it could reach $1 \%$ from total passengers per year, the business partner will gets around 630,156 customers per year. 630,156 customers per year multiplied by the number of products that could be sold so it can predict how much profit that business partner will get.

Space rental rates at Soekarno-Hatta airport were different for each terminal as it can be seen in Table 2 . Beside space rental costs that should be paid, business partners should pay a concession fees of $12 \%-18 \%$ from gross turnover earned by business partners to Airport managers depend on business line which carried out. These two cost components which have direct impact on selling price of products or services at the airport which higher than selling price of the product or service outside the airport.

\begin{tabular}{cc}
\hline Location & T ariff $/ \mathbf{m}^{2} / \mathbf{m o n t h}$ * \\
\hline Terminal 1 & IDR $350,000-$ IDR 500,000 \\
Terminal 2 & IDR 350,000-IDR 500,000 \\
Terminal 3 & IDR 500,000 - IDR 1,500,000 \\
\hline Table 2:- List of Average Space Rental Rates at Soekarno- & Hatta Airport \\
\multicolumn{2}{c}{ Source: PT Angkasa Pura II (Persero) Field Data (2018) }
\end{tabular}
(processed data) 
PT Angkasa Pura II (Persero) provides space rental rates that various at Soekarno-Hatta airport depending on how strategic that location is. In Terminal 1 and Terminal 2 , the average space rental rate per square meter was around IDR 350,000 - IDR500,000, while specifically in Terminal 3 Ultimate which was only operated in 2016, the average room rental rate per square meter on offer was around IDR 500,000 - IDR 1,500,000. The rates at Terminal 3 Ultimate were indeed different, because the building is new and modern and those check-in counter area is public area so not only passengers who have tickets which could enter that but also deliverers or other visitors could enter that check-in counter area without using a ticket.

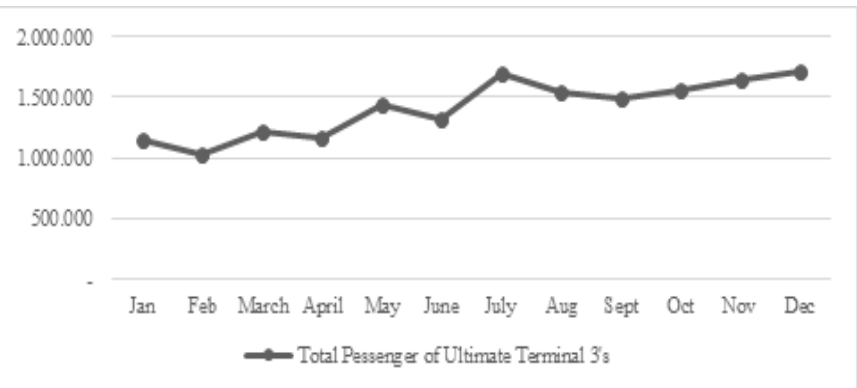

Fig 1:- The Ultimate Terminal 3's Passenger Growth in 2017

Source: PT Angkasa Pura II (Persero), 2018 (processed data)

Based on these pre-survey results, only 3 people stated that they were very frequent and 8 people often considered about the price when purchased products at Terminal 3 Soekarno-Hatta Airport. Meanwhile, 17 people stated that sometimes they considered price of their product, meaning that they have never considered the current price when purchase. Based on these pre-survey results, it was also found that all pre-survey respondents on average had feeling of being rushed at the airport.

Based on these phenomenon where time was limited at the airport, passengers still do other activities such as shopping or just eating and drinking at restaurants and coffee shops even though the product have high prices but they do not seem not effected to those people to buy products at the airport. Therefore, Researchers tried to examine those impact from price, brand image, time pressure towards purchase decisions and customer satisfaction over products at Terminal 3's Soekarno-Hatta Airport.

\section{LITERATURE REVIEW}

\section{A. Price}

The definition of price in a narrow mind is the amount of money charged for product or service, whereas in huge definition means the sum of all the value which customer gives up in getting the benefit of owning or using a product or service (Kotler and Armstrong, 2011). According to Kotler and Keller (2012: 383) price is one element from mix marketing which earned revenue, and other elements that could earned costs. Price also as one of the most adaptable elements compared to product features and distribution channels.

\section{B. Brand Image}

The America Marketing Association which defines a brand as a name, term, sign or symbol and combination of two or more of these elements, which are intended to identify goods and services from seller or group of sellers and distinguish them from competing products (Keller, 2013: 30).

\section{Time Pressure}

Time Pressure is time availability which felt by individual to perform those given task. Based on this definition, those perception becomes an emphasis that will change people information process. In broad terms, when viewed from these perspective of purchasing behavior, Lin, et al. (2013) stated that time pressure is a situational variable which influences customer decision making while in store because being busy creates contextual time pressure moment.

\section{Purchase Decision}

According to Kotler and Armstrong (2011:152), before making a purchase, literally consumers would go through five stages of purchase decisions, such as problem recognition, information search, alternative evaluation, purchase decisions and post-purchase behavior. Consumers do not always go through these five stages of purchase process the product entirely, they can go through and even reverse several stages (Kotler and Keller, 2012: 166).

\section{E. Customer Satisfaction}

According to Kotler and Keller (2012:177) satisfaction is the feeling of being happy or disappointed by someone who appears after comparing these performance (result) of the product or service which thought against these expected performance or results, if the performance is below the expectations of customer will not satisfied, if the performance meets customer expectations the customer would get satisfied and if performance exceeds customer expectations the customer would very satisfied or happy.

\section{F. Theoretical Framework}

Purchase decisions and satisfaction were explained by analyzing those influence from Brand Image, Price and Time Pressure. These analysis concept was described in diagram of theoretical framework, as its follows:

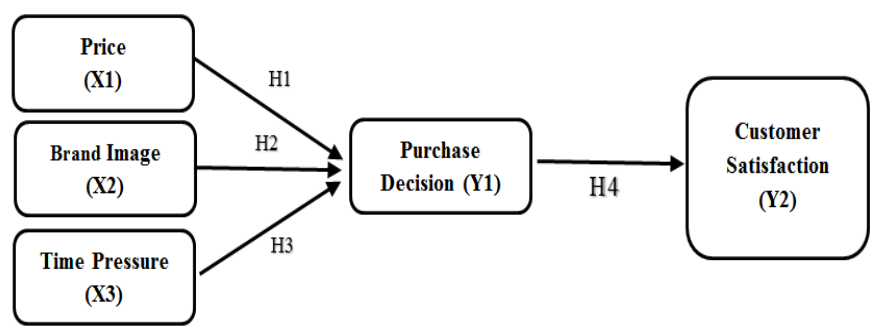

Fig. 2:- Theoretical Framework 


\section{G. Hypothesis}

Referring to discussion from these literature reviews and previous research, those several hypothesis could be developed as its follows:

H1: Price (X1) had significant influence on Purchase Decision (Y1) at Terminal 3 Soekarno-Hatta International Airport.

H2: Brand Image (X2) had significant impact on Purchase Decision (Y1) at Terminal 3 Soekarno-Hatta International Airport.

H3: Time Pressure (X3) had significant influence against Purchase Decision (Y1) at Terminal 3 Soekarno-Hatta International Airport.

H4: Purchase Decision (Y1) had significant impact to Customer Satisfaction (Y2) at Terminal 3 Soekarno-Hatta International Airport.

\section{METHODOLOGY}

This research type was conclusive research that used to support decision makers in finding, evaluating and selecting a series of actions that should be taken in certain situations. These exogenous variables consist of price, brand image and time measurement. The intervening variable consists was purchase decision. Endogenous variable was detected from Customer Satisfaction. The intervening variable was purchasing decision while the endogenous variable on this research was customer decision. These variables were measured through a Likert scale. These data analysis technique used Structural (SEM) which assisted by the Lisrel (Linear Structural Relations) program. The reason for adding this SEM method because SEM could examined these theories with data and allows variable to act dynamically where the variable can act as independent variable in a model. These research population were passengers who passed through terminal 3 departure at Soekarno-Hatta International Airport with sample size of 120 respondents. The sampling technique used non probability sampling techniques or non-random samples.

\section{RESULT AND DISCUSSION}

\section{A. Demographic Characteristics of Respondents}

Based on gender from the respondents, the majority of respondents were female, which is $70 \%$. This because in modern life like now, women's activities are not only at home, but also outside for various reasons. Based on respondents age, the majority of respondents were 31 to 40 years old, which was 59\%. This is because this age range includes in productive age, starting from employees, travelers who have a lot of activities outside the home, where their health is still maintained so they are capable to travel far and that age already has the confidence and courage to use public transportation. Characteristics of respondents based on occupation, most of them were private employee and BUMN's Employee respondents were as much as $75 \%$. This is because beside making official trips which paid by the company, the respondents already have pocket money and income. So respondents can afford to buy their own public transportation tickets for personal activities. Based on the length of time before take-off, the majority was, 45 minutes to 75 minutes as much as $75 \%$. This is because respondents wants to reduce the risk of waiting too long for departure hours. Respondents chose the ideal time to arrive at the airport according to the time of departure. To fill the waiting time, passengers usually have several activities such as reading books, watching movies, enjoying free facilities provided by the airport, dining at restaurants or mini markets and shopping for items that may be needed or liked as souvenirs.

\begin{tabular}{|c|c|c|c|}
\hline No. & Description & $\begin{array}{c}\text { Frequency } \\
\text { (Person) }\end{array}$ & $\begin{array}{c}\text { Percentage } \\
(\%)\end{array}$ \\
\hline \multirow{3}{*}{1} & Respondents Gender & & \\
\hline & - Male & 35 & 29.17 \\
\hline & - Female & 85 & 70.83 \\
\hline \multirow{7}{*}{2} & Ages & & \\
\hline & - Less than 20 years old & 9 & 7.50 \\
\hline & - Between 21 - 30 years old & 16 & 13.33 \\
\hline & - Between 31 - 40 years old & 71 & 59.17 \\
\hline & - Between 41 - 50 years old & 17 & 14.17 \\
\hline & - More than 50 years old & 7 & 5.83 \\
\hline & Profession & & \\
\hline \multirow{5}{*}{3} & - Student/Student Collage & 6 & 5.00 \\
\hline & - Private Employee & 38 & 31.67 \\
\hline & - Civil Servants/BUMN/BUMD & 53 & 44.17 \\
\hline & - Entrepreneur & 18 & 15.00 \\
\hline & - Others & 5 & 4.17 \\
\hline \multirow{6}{*}{4} & Length of arrival time before $t$ & & \\
\hline & - Less than 45 minutes & 13 & 10.83 \\
\hline & - Between 45 - 60 minutes & 51 & 42.50 \\
\hline & - Between 61 - 75 minutes & 31 & 25.83 \\
\hline & - Between 76 - 90 minutes & 20 & 16.67 \\
\hline & - More than 90 minutes & 5 & 4.17 \\
\hline
\end{tabular}

Table 3:- Demographic Characteristics of Respondents Source: Author's analysis results (2020)

\section{B. Goodness of Fit Test}

The goodness of fit test was created to find out how well the resulting model describes to the actual conditions. Research data processed was carried out by maximum likelihood method which was carried out by Lisrel 8.80 application. From these research results, it can be seen that the model fit value shows good value, such as good fit and marginal fit, meaning that the whole value of the goodness fit test shows good fit. 
ISSN No:-2456-2165

\begin{tabular}{lcccc}
\hline \multirow{2}{*}{ Goodness of Fit Measurement } & \multicolumn{2}{c}{ Fit Measurement } & \multicolumn{2}{c}{ Measurement Result } \\
\cline { 2 - 3 } & Good Fit & Marginal Fit & & \multicolumn{2}{c}{ Fit } \\
\cline { 2 - 3 } Normed Chi-Square $\left(\chi^{2} / \mathrm{df}\right)$ & $<2.0$ & & 1.173 & Fit \\
P Value & $0.05<\mathrm{p}<1.00$ & $0.01<\mathrm{p}<0.05$ & 0.074 & Fit \\
Root Mean Square Error (RMSEA) & $<0.08$ & & 0.038 & Fit \\
Root Mean Square Residual (RMR) & $<0.05$ & & 0.017 & Fit \\
Goodness of Fit Index (GFI) & $=0.90$ & $0.70<0.90$ & 0.87 & Marginal Fit \\
Normal Fit Index (NFI) & $=0.90$ & $0.80-<0.90$ & 0.98 & Fit \\
Non-Normed Fit Index (NNFI) & $=0.90$ & $0.80-<0.90$ & 0.99 & Fit \\
Comparative Fit Index (CFI) & $=0.90$ & $0.80-<0.90$ & 1.00 & Fit \\
Increamental Fit Index (IFI) & $=0.90$ & $0.80-<0.90$ & 1.00 & Fit \\
Relative Fit Index (RFI) & $=0.90$ & $0.80-<0.90$ & 0.97 & Fit \\
\hline
\end{tabular}

Table 4:- Goodness Fit Test Results

Source: Primary data processed by LISREL

\section{Measurement Model Evaluation}

The results of analysis data processed which shows that those indicators from latent variables (constructs) show good validity,such as the value of standardized loading factor $(\mathrm{SLF}) \geq 0.50$. The value of construct reliability price (CR)of 0.91 was greater than 0.70 and the variance extracted (VE) value of 0.78 was greater than 0.50 which indicated that each indicator which formed this latent variables had good reliability.

\begin{tabular}{lccccc}
\hline Indicator & \multirow{2}{*}{$\begin{array}{c}\text { Code } \\
\text { SLF }\end{array}$} & $\begin{array}{c}\text { Standard } \\
\text { Errors }\end{array}$ & \multicolumn{2}{c}{ Reliability } & \multirow{2}{*}{ Information } \\
\hline PR1 & 0.75 & 0.20 & & VE $\geq 0,5$ & \\
PR2 & 0.79 & 0.11 & 0.91 & 0.78 & Valid \\
PR3 & 0.76 & 0.19 & & & Valid \\
\hline
\end{tabular}

Table 5:- reliability and validity from price's constructs

Results from data processing analysis shows that indicators of latent variables (constructs) shows good validity, which is standardized loading factor(SLF) value $\geq$ 0.50 . Construct reliability (CR) value from brand image was 0.97 which greater than 0.70 with variance extracted (VE) value was 0.88 which greater than 0.50 which indicates that each that shaped indicator from latent variables had good reliability.

\begin{tabular}{|c|c|c|c|c|c|}
\hline \multirow{2}{*}{$\begin{array}{c}\text { Indicator } \\
\text { Code }\end{array}$} & \multirow{2}{*}{ SLF } & \multirow{2}{*}{$\begin{array}{c}\text { Standard } \\
\text { Errors }\end{array}$} & \multicolumn{2}{|c|}{ Reliability } & \multirow{2}{*}{ Information } \\
\hline & & & $\mathrm{CR} \geq 0,70$ & $\mathrm{VE} \geq 0,5$ & \\
\hline BI1 & 0.87 & 0.10 & \multirow{4}{*}{0.97} & \multirow{4}{*}{0.88} & Valid \\
\hline BI2 & 0.92 & 0.10 & & & Valid \\
\hline $\mathrm{BI} 3$ & 0.82 & 0.10 & & & Valid \\
\hline BI4 & 0.81 & 0.11 & & & Valid \\
\hline
\end{tabular}

Table 6:- Reliability and Validity from Brand image's constructs

Those results from data processing analysis shows that indicators of latent variables (constructs) show good validity, which is standardized loading factor (SLF) value $\geq$ 0.50. With construct reliability (CR) value from Time Pressure 0.95 was greater than 0.70 and variance extracted (VE) value was 0.82 which greater than 0.50 and indicated that each indicator that shaped this latent variables had good reliability.

\begin{tabular}{|c|c|c|c|c|c|}
\hline \multirow{2}{*}{$\begin{array}{c}\text { Indicator } \\
\text { Code }\end{array}$} & \multirow{2}{*}{ SLF } & \multirow{2}{*}{$\begin{array}{c}\text { Standard } \\
\text { Errors }\end{array}$} & \multicolumn{2}{|c|}{ Reliability } & \multirow{2}{*}{ Information } \\
\hline & & & $C R \geq 0,70$ & $\mathrm{VE} \geq 0,5$ & \\
\hline TP1 & 0.69 & 0.07 & \multirow{4}{*}{0.95} & \multirow{4}{*}{0.82} & Valid \\
\hline TP2 & 0.68 & 0.10 & & & Valid \\
\hline TP3 & 0.66 & 0.14 & & & Valid \\
\hline TP4 & 0.66 & 0.09 & & & Valid \\
\hline
\end{tabular}

Table 7:- Reliability and validity from Time Pressure's construct

Those results from data processing analysis shows that indicators of latent variables (constructs) shows good validity, which is the value of standardized loading factor $(\mathrm{SLF}) \geq 0.50$. And construct reliability (CR) value of Purchase Decision was 0.97 which greater than 0.70 and variance extracted (VE) value was 0.85 which greater than 0.50 and it was indicated that each indicator that shaped these latent variables had good reliability.

\begin{tabular}{|c|c|c|c|c|c|}
\hline \multirow{2}{*}{$\begin{array}{c}\text { Indicator } \\
\text { Code }\end{array}$} & \multirow{2}{*}{ SLF } & \multirow{2}{*}{$\begin{array}{c}\text { Standard } \\
\text { Errors }\end{array}$} & \multicolumn{2}{|c|}{ Reliability } & \multirow{2}{*}{ Information } \\
\hline & & & $C R \geq 0,70$ & $V E \geq 0,5$ & \\
\hline PD1 & 0.78 & 0.12 & & & Valid \\
\hline PD2 & 0.75 & 0.06 & & & Valid \\
\hline PD3 & 0.75 & 0.08 & 0.97 & 0.85 & Valid \\
\hline PD4 & 0.68 & 0.10 & & & Valid \\
\hline PD5 & 0.68 & 0.11 & & & Valid \\
\hline
\end{tabular}

Table 8:- Reliability and Validity from Purchase Decision's construct

Results from data processing analysis shows that those indicators of latent variables (constructs)had shown good validity, which is the value of standardized loading factor $(\mathrm{SLF}) \geq 0.50$ with Customer Satisfaction construct reliability $(\mathrm{CR})$ value was 0.98 which greater than 0.70 and variance extracted (VE) value was 0.91that greater than 0.50 which indicated that each indicator that shaped these latent variables had good reliability.

\begin{tabular}{|c|c|c|c|c|c|}
\hline \multirow{2}{*}{$\begin{array}{c}\text { Indicator } \\
\text { Code }\end{array}$} & \multirow{2}{*}{ SLF } & \multirow{2}{*}{$\begin{array}{c}\text { Standard } \\
\text { Errors }\end{array}$} & \multicolumn{2}{|c|}{ Reliability } & \multirow{2}{*}{ Information } \\
\hline & & & $\mathrm{CR} \geq 0,70$ & $\mathrm{VE} \geq 0,5$ & \\
\hline CS1 & 0.91 & 0.12 & \multirow{4}{*}{0.98} & \multirow{4}{*}{0.91} & Valid \\
\hline $\mathrm{CS} 2$ & 0.93 & 0.11 & & & Valid \\
\hline $\mathrm{CS} 3$ & 0.86 & 0.00 & & & Valid \\
\hline $\mathrm{CS} 4$ & 0.80 & 0.08 & & & Valid \\
\hline
\end{tabular}

Table 9:- Reliability and Validity of Customer Satisfaction's construct 


\section{Structural Model Fit Test}

Based on those results from structural model LISREL analysis, the connection between these exogenous variable such as price, brand image to endogenous which is purchase decision and customer satisfaction could be further explained as its follows:

$>$ Price variable towards purchase decision chooses to have a t-value of 6.65 where this value was greater than 1.96 , in this case it shows positive and significant influence between these two variables. Based on Figure 4.11 , those amount of these influence was 0.53 .

Brand image variable on purchase decision chooses to have a t-value of 4.28 where this value was greater than 1.96 , in this case it shows positive and significant influence between these two variables. Based on Figure 4.11, the amount of these influence was 0.25 .

$>$ Time preassure variable over purchase decision chooses to have a t-value of 2.94 where this value was greater than 1.96 , in this case it shows positive and significant influence between these two variables. Based on Figure 4.11, the amount of these influence was 0.20.

$>$ Purchase decision variable towards Customer Satisfaction directly has a t-value of 11.13 where value was greater than 1.96 , in this case it shows positive and significant influence between these two variables. Based on Figure 4.11, the magnitude of these influence was

0.95 .
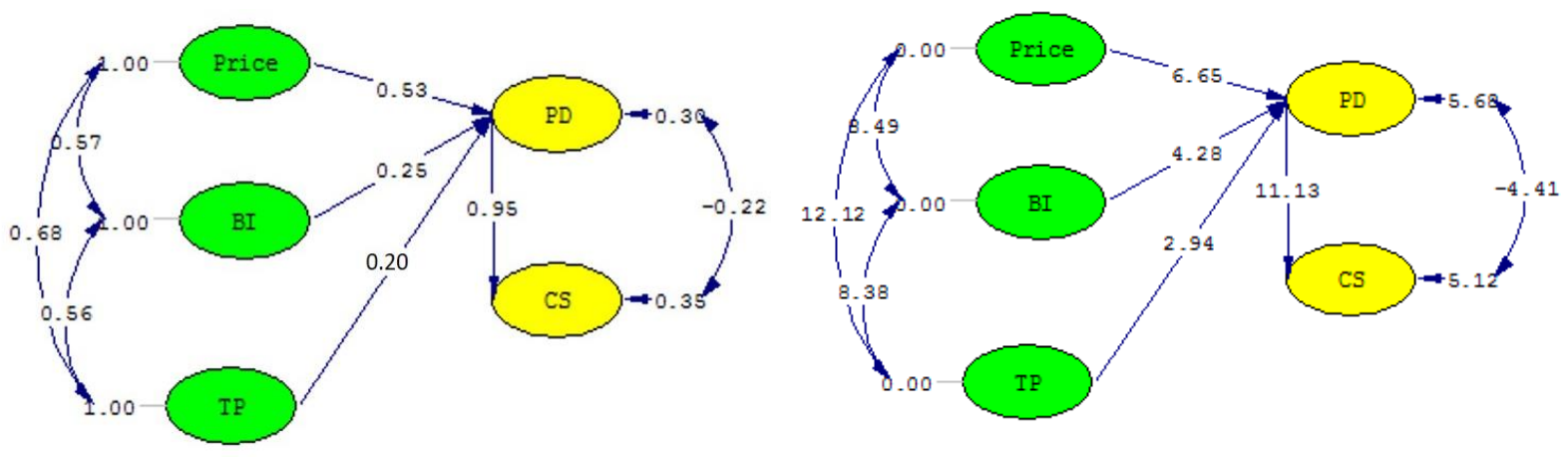

Fig. 3:- Standardized Solution and T-Value Structural Model

Based on these test results, the coefficient of determination or R-square (R2) in LISREL analysis could be explained as its follows:

$>$ The value of squared multiple correlation in the first equation was 0.71 . This value shows that $71 \%$ of these variation in purchase decision value was determined by the variation in the value of variable price, brand image and time preassure.

$>$ The value from squared multiple correlation in the second equation was 0.60 . This value was indicated that $60 \%$ from variation in participant's Customer Satisfaction value was determined by the variation from value of purchase decision variable.

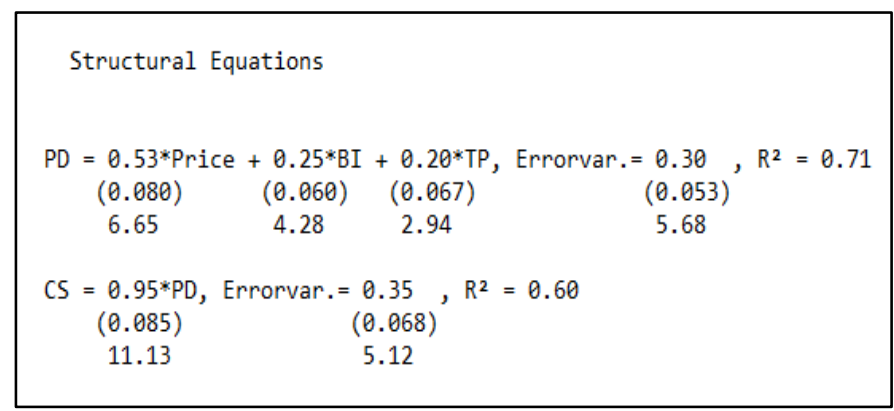

Fig 4:- Structural Equations

Source: Primary data processed by LISREL

\section{E. Hypothesis Test}

Basically, these hypothesis test was an answer to various kinds of relationships which developed in the structural model. This model shows a relatively comprehensive pattern of relationships between various research variables, both in context of direct relationship (direct influence) and indirect relationship (indirect influence ). The t-value and structural equation coefficient were used to examined those hypothesis in this research. The results from this evaluation could be summarized in Table 10, these hypothesis test calculation could be describe as its follows:

\begin{tabular}{|c|c|c|}
\hline Connection Between Constructs & T-Values & Information \\
\hline Price-> Purchase Decision & 6.65 & ve and Significant \\
\hline Brand Image $->$ Purchase De & 4.28 & Positive and Significant \\
\hline Time Pressure $>>$ Purchase Decision & 2.96 & ificant \\
\hline Purchase Decision $>$ Consumer Loyalty & 11.13 & Positive and Significant \\
\hline
\end{tabular}

Table 10:- Calculation of Hypothesis Test

Source: Primary Data Processed (2020)

\section{F. Discussion}

These hypothesis research $(\mathrm{H} 1)$ defined that Price had directly positive and significant influence on Purchase decision. These results were in line with research from Mirza et.al (2017) which stated that there had positive connection between perceptions of price and purchasing decisions.

These hypothesis research $(\mathrm{H} 2)$ were described that Brand image had directly positive and significant impact towards Purchase Decision. These results were confirm with the results from Perng's (2010) which found that branded products provide the most satisfaction when doing 
purchases at the airport. Passengers tend to choose to purchase those products which have a good brand image.

These hypothesis research (H3) stated that Time Pressure had directly positive and significant direct impact towards Purchase decision. These results were in line with results from Lee et.al's (2017) research, which said that time pressure had positive influence towards an impulsive buying and repurchase intention. In other words, if Time Pressure was high, so it does conversely with purchasing decisions that took by customers. Meaning that the presence of time pressure felt by consumers when shopping can encourage to customers to make an unplanned purchase at terminal 3 Soekarno-Hatta International airport.

These hypothesis research (H4) defined that Purchase decision had directly positive and significant impact towards Customer Satisfaction. These results were confirmed those results from Mirza et.al (2017) which provide those information if there had positive connection between customer satisfaction and purchase decisions. In other words, if Purchase decision has increased, it will affect Customer Satisfaction. Satisfaction is whole attitude shown by customers towards the goods or services after they obtained and used them. Customer Satisfaction is reflects from someone opinion regarding product performance which relate to their expectations. When they put their hopes high on products sold at terminal 3 Soekarno-Hatta International airport.

\section{G. Managerial Implications}

According to respondents' responds towards statement from those indicators, researchers will used them as input for management of Angkasa Pura II.

$>$ Passengers or customers who did purchases while waiting for departure at commercial airport outlets shows that the indicator in price variable distribution results, states that there has a match between price and quality of the product that being purchased. However, some of respondents considered that the prices of products sold at Terminal 3 Soekarno-Hatta Airport were not reasonable. And This should be considered, because not all passengers at Terminal 3 airport have high income. Therefore, the price of product should be adjusted to its quality. For this reason, need an efforts to maintain these conditions. In determining better price and its implemented accordingly, Angkasa Pura II and their business partners should look to qualities from its product, so it could gave some impact to the level of customer purchase decisions. This has an intended to maintained purchase decisions high and keep it from decline.

> Respondents was indicated that those indicators from Brand image's distribution results defined that customers buy products which give them a good impression in form of pride because branded products provide the most satisfaction while doing purchase at the airport. Passengers tend to choose to purchase those products which have a good brand image and this should be continuously improved and maintained to be more selective in choosing partners.
Respondents was indicated that those indicator in time pressure variable distribution result defined that customers still have free time to shop, its better if food stores, clothing drinks and others are close to each other so customers would have many opportunities to switch from one store to another.

$>$ Those influence of price, brand image and time pressure towards purchase decisions had impact on Customer Satisfaction, where the increasing in business competition is getting tough and more competitive, it makes their business partners at Terminal 3 SoekarnoHatta International Airport. Create those various programs to increase Customer Satisfaction and create more innovative products for long term. Innovation is not only about creating products and services, but also to touch more and know how to maintain customers. This is necessary to have competitive advantage than others companies which engaged in the same field.

\section{CONCLUSION AND SUGGESTION}

\section{A. Conclusion}

This research aims to analyze "Those influence from price, brand image, time pressure towards purchase decisions and customer satisfaction over products at Terminal 3 Soekarno-Hatta Airport". According to these data analysis and discussion which described in prior chapter, several research conclusions can be drawn as follows:

$>$ Price variable had positive and significant influence towards purchase decision.

$>$ Brand image variable had positive and significant influence towards purchase decisions

$>$ Time pressure variable had positive and significant impact towards purchase decisions.

$>$ Purchase decision variable had positive and significant impact to Customer Satisfaction

\section{B. Suggestion}

By analyzing these research results, there has some suggestions that could be considered as an input or recommendation for Angkasa Pura II management and their business partners at terminal 3 Soekarno-Hatta airport as well as for further researchers are as its follows:

$>$ PT Angkasa Pura II (Persero) need to always adjust the rental price for business owners so those price of products or services sold by business partners would maintained and affordable to customers. This has to be done to control prices, its mainly aimed to preventing price wars from same product, especially when facing the decreasing on demand.

$>$ Business partners should increase their brand image, because customers felt that the brand image indicator which has the lowest value and there were still many passengers or customers who cannot remember those brand of certain products which usually purchased from outside the airport. Even though they already have a strong brand image thought, business partners should have the right strategy to anticipated those impact from high price of rental space and concession prices at airports. This certainly has impact to price of the 
product that sold there. But not all products sold at the airport already have a brand image, for partners whose brands have not entered the top brands, business partners have to capable to build a positive brand image for customers which could be done by giving positive experience which felt by consumers when doing a purchase. products, such as their unique packaging design, presentation style and easy to pronounce names can enhance purchasing decisions.

Passengers or customers at the airport do not have enough time to take many things into consideration, so it would increase possibility that customers would make unplanned purchases at the airport, this should be chance for business partners to manages its locations to waiting room, create strategy that bring more customers to the store by making the store environment as attractive as possible to attract consumer attention and buy products in store without worrying about the price due to time limitee. This all need to be done to increase sales and customer satisfaction.

As for next researcher is expected to be able to conduct these research by adding other variables which has affection towards satisfaction and purchasing decisions, such as price, service, trust, security. Therefore it could enrich those factors that need to be studied related to customer satisfaction where research requires a lot of development in various sectors, so the results of these research would give positive and applicable contribution to the world of education in general and also particular in developing the company's business.

\section{REFERENCES}

[1]. Keller, K. L.(2013).Strategic Brand Management, $4^{\text {th }}$ Edition. Harlow:Pearson Education Limited

[2]. Kotler, P., \& Amstrong, G. (2011). Principles of Marketing, $14^{\text {th }}$ Edition. New Jersey:Pearson Prentice Hall.

[3]. Kotler, P., \& Keller, K. L. (2012). Marketing Management, $14^{\text {th }}$ Edition. New Jersey:Pearson Prentice Hall.

[4]. Lee, K-Y., Yu -Jin Choi \& Jin-Woo Park (2017). A Study on Effects of Time Pressure Perceived by Users of Airport Duty-free Shop on Impulsive Purchasing Behavior and repurchase. International Business Research, Vol. 11, No. 1; 2018;ISSN 1913-9004 EISSN 1913-9012.

[5]. Lin, Yi-Hsin., \& Chen, Ching-Fu. (2013). Passengers' shopping motivations and commercial activities at airports e The moderating effects of time pressure and impulse buying tendency. Tourism Managment, Vol. 36, 426-434.

[6]. Mirza, B. \& Ali, M. (2017). An assessment of relationship among service quality, price perception and customer satisfaction in the formation of consumer's purchase intention. Arabian Journal of Business and Management Review”. Vol.6 (12).

[7]. Perng, S-W.,, Chia-Chuan Chowa \& Wu-Cheng Liao (2010). Analysis of shopping preference and satisfaction with airport retailing products. Journal of Air Transport Management, Vol.16, 279-283. 